\title{
НАРИС ІСТОРИЧНОГО РОЗВИТКУ КРИМІНАЛЬНОЇ ВІДПОВІДАЛЬНОСТІ ЗА УХИЛЕННЯ ВІД СПЛАТИ ПОДАТКІВ ТА ІНШИХ ПЛАТЕЖІВ
}

\author{
Гритенко О. А., Старинець $\epsilon$. А.
}

\begin{abstract}
у статmі досліджено історичний розвиток кримінальної відповідальності за ухилення від сплати податків та інших платежів. Проаналізовано історичні аспекти виникнення та становлення кримінальної відповідальності за ухилення від сплати податків та інших зборів. Сформульовано етапи виникнення та розвитку законодавства про злочинне ухилення від сплати податків і платежів в Україні. Встановлено, що за час історичного розвитку відповідальності за ухилення від сплати податків та інших платежів в державі існували громадяни, які не бажали сплачувати податки і всіляко ухилялися від цього, тому держава протягом століть намагалась зібрати максимальну кількість податків і не допустити ухилення від їх сплати, застосовуючи різні форми відповідальності, зокрема і кримінальну.

Ключові слова: злочин, податок, збори, кримінальна відповідальність, ухилення.
\end{abstract}

В статье исследовано историческое развитие уголовной ответственности за уклонение от уплаты налогов и других платежей. Проанализированы исторические аспекты возникновения и становления уголовной ответственности за уклонение от уплаты налогов и других сборов. Сформулированы этапы возникновения и развития законодательства о преступном уклонении от уплаты налогов и платежей в Украине. Установлено, что за время исторического развития ответственности за уклонение от уплать налогов и других платежей в государстве существовали граждане, не желающие платить налоги и всячески уклоняющиеся от этого, поэтому государство в течение веков пыталось собрать максимальное количество налогов и не допустить уклонения от их уплаты, применяя различные формы ответственности, в частности и уголовной.

Ключевые слова: преступление, налог, сборы, уголовная ответственность, уклонение.

The article is devoted to the historical development of criminal liability for tax evasion and other payments. The historical aspects had been analyzed of the genesis and formation of criminal liability for tax evasion and other charges are analyzed. Liability for non-payment of taxes was established earlier than for non-payment of other payments. It was defined that the most preferred criminal liability design was one where there was no comprehensive list of evasion methods, or no indication of the method at all. It was formulated the genesis stages of the emergence and development of legislation on criminal tax evasion and payments in Ukraine. There is a separation of conditional stages into: registration of fiscal functions of the ancient Russian state, as well as the establishment of separate rules for tax evasion and other payments; establishing responsibility for non-payment of payments and taxes separately in each principality; consolidation and formation of the system of responsibility for non-payment of taxes and customs payments; codification work and gradual preparation of a well-structured system of administrative and criminal liability for non-payment of taxes

Гритенко О. А., Старинець Є. А., 2019 and payments; gradual transition from administrative to criminal liability for non-payment of taxes; additions to the criminal legislation, articles of criminal law concerning tax of payments to the budgets, as well as reformation of tax and customs legislation; and at list criminalization of acts in the form of non-payment of taxes and other payments. It is proved that during all the historical development of the responsibility for tax evasion and other payments in the state there were citizens who did not want to pay taxes and in every way evade it, and accordingly, the state throughout the centuries tried to collect the maximum amount of taxes and prevent evasion from them, payment using different forms of liability, in criminal law.

Key words: crime, tax, fees, criminal liability, evasion.

Постановка проблеми та їі актуальність. Сучасна система відповідальності за несплату податків та інших платежів має тривалу історію формування, завдяки якій кримінальна відповідальність за вказані діяння відповідає всім основним ознакам юридичної відповідальності, але при цьому має низку специфічних особливостей.

Зокрема, це те, що законодавство, що передбачає відповідальність за несплату податків та інших платежів, вельми нестійке і має властивість постійно змінюватися. Це пов'язано з тим, що податки та інші платежі використовуються як економічні інструменти, тобто в певні періоди і відповідно до конкретних потреб держави вони повинні відмінятися, обнулятися або, навпаки, збільшуватися.

Проте відповідальність за несплату податків та інших платежів виникає одночасно з появою таких. Це нерозривно пов'язано з появою i оформленням держави і виконанням нею своїх функцій. Отже, без системи податків та інших платежів держава існувати не може.

Аналіз останніх досліджень і публікацій. Проблеми кримінально-правових аспектів ухилення від оподаткування були досліджені у працях П.П. Андрушка, Л.П. Брич, В.М. Вересова, А. Веткіна, В. Вишневського, П.А. Вороб'я, Н.О. Гуторової, О.О. Дудорова, А. Крисоватого, Я.М. Кураш, І. Мельника, В.Р. Мойсика, В.В. Лисенка, В.О. Навроцького, Л. Омеляновича, С. Онисько, О.І. Перепелиці, Ю.М. Сухова, Є.Л. Стрельцова та інших вчених.

Метою статті $\epsilon$ проведення комплексного дослідження історичних джерел, які висвітлюють становлення кримінальної відповідальності за ухилення від сплати податків, зборів (обов'язкових платежів), що дозволить сформулювати етапи виникнення та розвитку законодавства про злочинне ухилення від сплати податків та інших платежів в Україні.

Виклад основного матеріалу. Відповідальність за несплату податків, зборів та інших платежів розвивалася в різний час. Зокрема, відповідальність за несплату податків була встановлена раніше, ніж за 
несплату інших платежів, і безпосередньо була пов'язана з формуванням першої податкової системи Стародавньої Русі, яка існувала ще до прийняття християнства. Відповідно до цієї системи кожен, що знаходився під владою князя, був зобов'язаний віддати в рахунок податку те, що міг [4, с. 207-488].

У міру розширення впливу Київської Русі змінювалася і податкова система. Тепер вже князь зі своєю дружиною виїжджав для збору податку, забираючи все, що заслуговувало, на його погляд, уваги. Ніякої системності, економічно обґрунтованих стабільних норм в оподаткуванні в цей період не було. Зібране у вигляді податків часто наступного дня відправлялося на далекі ринки сусідніх держав, здебільшого до Візантії. Така податкова політика спричиняла протести населення. Вперше централізована і впорядкована система спадкування (постійні величини податкових ставок, визначені місця збору податкових платежів, торгівлі та обміну), з'явилась у 945-962 рр. Зібрані податки йшли на утримання князя і його наближених, церкви [1, с. 91]. Що стосується законодавчого закріплення норм, які регулюють оподаткування, то слід вказати окремі статті «Руської Правди». Зокрема, у статтях 42, 43 короткої редакції і статтях 96, 97 «Руської Правди» встановлюються такі види податків, як корм, городові й мостові гроші [8, с. 282].

Таким чином, до початку періоду татаро-монгольської навали в Стародавній Русі були сформовані певні основи відповідальності за несплату податків і платежів. При цьому відповідальність за несплату податків була структурована і закріплена в «Руській Правді», а відповідальність за несплату платежів лише починала оформлюватися. Однак ці процеси були завершені з початком монголо-татарської навали, яка змінила всю податкову систему того часу.

Податкові платежі в цей період стали формою плати за спокійне існування. Контроль над збором податків здійснювали намісники-баскаки. При несплаті податку або його сплаті в неповному розмірі баскак повідомляв ЗолотуОрду, апокараннянезмушувалосебедовгочекати. Каральні походи Орди надовго відбивали охоту не сплачувати податки. Однак корупція не оминула і намісників Золотої Орди, внаслідок чого інститут баскаків поступово втратив своє значення і був знищений [9, с. 112].

Про відповідальність за несплату платежів також ідеться і в Білозерській митній грамоті 1497 р. [11, с. 217] та інших джерелах, а також в основному джерелі кримінального права того періоду - Судебнику 1497 р.

Отже, юридична відповідальність за несплату податків і платежів існувала ще за часів Київської Русі, однак при цьому певної системи відповідальності за ухилення від сплати податків або платежів ще не склалося. Монголо-татарська навала не сприяла оформленню такої системи. У цей період відповідальність за несплату податків і платежів застосовувалася, проте в основних кримінально-правових джерелах цього періоду вона не закріплювалася. Водночас відсутність системи відповідальності не означала, що покарання за несплату податків не застосовувалося. Так, в 1533-1584 рр. за різними звинуваченнями в несплаті податків було страчено понад 500 людей [9, с. 134].

Якісно новий етап у встановленні відповідальності за несплату податків та платежів почався у 1613-1645 рр. Тоді відбувалися процеси упорядкування і системати- зації податкових інститутів. Однак юридично ці зміни в цей період закріплювалися ще безсистемно. Проте це підготувало підґрунтя для подальших перетворень.

У цей період вперше з'явився бюджет. Видавалися розшукові накази, головна роль яких - контроль над царськими чиновниками, що стежили за надходженням податкових платежів, а також припинення посадових злочинів. Був уведений податок з бояр і купців. Наслідком цих процесів було посилення відповідальності за ухилення від сплати податків. Так, Соборним уложенням 1649 р. [12, с. 488] встановлювалась відповідальність за несплату податків. Недобросовісні платники податків піддавалися публічному биттю батогами на торгу (правежу). Відповідача били по ногах. Тривалість покарання залежала від суми несплаченого податку.

Наступний етап у встановленні відповідальності за ухилення від сплати податків та платежів (16821725 рр.) не міг залишити без уваги податкову систему. Податкові повинності в умовах довгої Північної війни (1700-1721 рр.) були просто необхідні для ведення великомасштабних військових дій. Для цього в період з 1718 р. до 1724 р. відбувся перепис всього чоловічого населення. Відомості про чоловіків незалежно від віку вносилися в ревізькі казки. У них включалися відомості про власників дворів і членів їхніх сімей. Жіноче населення включалося в казки, але не враховувалося в зведених таблицях.

Черговий етап встановлення відповідальності за несплату податків i платежів охоплював період 1762-1796 рр. У цей період була вжита низка заходів з метою систематизації податкової системи. Були створені експедиції державних доходів, ревізій, відбувалися справляння недоїмок. Принципово змінилася податкова політика. Однак відповідальність за несплату податків все ще залишалася переважно адміністративною.

Встановлення кримінальної відповідальності безпосередньо пов'язане 3 кодифікаційною роботою, що проводилась на початку XIX століття. Наслідком такиХ кодифікаційних робіт було те, що у 1845 р. вступила в силу «Ухвала про покарання кримінальних та виправних» [14, с. 417], в якій, зокрема, детально описувалися склади податкових злочинів. Стаття 598 глави 4 Уложення встановлювала, які винні дії були підставою притягнення до відповідальності. Так, відповідальність наставала лише за наявності шкоди скарбниці держави у вигляді несплачених податків. Вперше в цій статті встановлювалася відповідальність не тільки власника заводу й інших служителів заводу, які вчиняли злочини без відома власника заводу, але і відповідальність підприємства, на якому було скоєне правопорушення. Таким чином, відповідальність за податкові злочини в XIX столітті в цілому оформилася і мала здебільшого фінансовий характер.

Кримінальна відповідальність за несплату податків в дореволюційному праві з'явилася в Кримінальному уложенні 1903 року [6, с. 114]. В цілому в цей період була сформована і діяла певна система відповідальності за несплату платежів і податків, яка включала як фінансову, так і адміністративну та кримінальну відповідальність. Однак головною все ж була відповідальність адміністративна.

Окремим етапом розвитку кримінальної відповідальності за ухилення від сплати платежів слід визнати період радянської влади. Так, першим кодифікованим 
джерелом кримінального права в цей період, який закріпив кримінальну відповідальність за вказані злочини, став КК 1922 р. Тут містилися чотири статті, що передбачали відповідальність за ухилення від сплати податків. Зокрема, це ст. 62 «Участь в організації, що діє в контрреволюційних цілях, а також підбурення населення до несплати податків», ст. 78 «Масова відмова від внесення грошових або натуральних податків», ст. 79 «Несплата окремими громадянами в строк або відмова від сплати грошових або натуральних податків», ст. 83 «Агітація і пропаганда всякого роду, що містить заклик до вчинення злочинів, передбачених ст. 78-79».

Примітною особливістю зазначених складів було те, що вони містилися в розділі 1 Особливої частини КК 1922 р., розділі 1 «Про контрреволюційні злочини» (ст. 62) та розділі 2 «Злочини проти порядку управління» (ст.ст. 78-79, 83). Згідно зі ст. 79 несплата податків вперше передбачала накладення адміністративного стягнення. Лише в разі повторної або злісної несплати до платника податків застосовувалися заходи кримінального покарання. Найбільш тяжкими з зазначених злочинів були злочини, передбачені ст.ст. 62,78. Вони передбачали покарання аж до розстрілу. Покарання за інші податкові злочини передбачали позбавлення волі від 6 місяців до 10 років, примусові роботи або конфіскацію майна.

Слід вказати також на те, що стаття 82 Кк 1922 р. мала певну особливість, яка полягала в тому, що у разі вчинення злочину, передбаченого ст. 78, за малосвідомістю суду надавалося право застосувати умовне засудження.

3 прийняттям КК 1922 р. і після закінчення деякого часу відбувся значний приріст податкових злочинів. Так, в 1924 році число засуджених за ухилення від державних повинностей становило 26152 людини [15, с. 4].

Наступний КК 1926 р., зберігаючи традиції попереднього кодексу, був вдосконалений i доповнений новими складами податкових злочинів. Кримінальна відповідальність за ці злочини, як і в попередньому КК 1922 р., була передбачена в розділах про контрреволюційні злочини (гл. 1) і злочини проти порядку управління (гл. 2).

Перша глава, закріпивши відповідальність за участь в організації, що діє в контрреволюційних цілях, а також підбурення населення до несплати податків (ст. 586), була доповнена складом пропаганди і агітації до повалення влади рад шляхом масового невиконання податкових повинностей (ст. 5813). За вказані дії був встановлений найвищий ступінь покарання.

У розділі 2 були збережені такі злочини, як масова відмова від внесення грошових або натуральних податків (ст. 595), агітація і пропаганда до скоєння злочину, передбаченого ст. 595 (ст. 596). Осатаній із зазначених злочинів зберіг жорстку відповідальність за агітацію під час війни і покарання у вигляді смертної кари.

Склад злочину «несплата податків» був розділений залежно від виду податку на два нових склади злочину, які передбачали:

- несплату в установлений термін податків або зборів за обов'язковим окладним страхуванням (ст. 60);

- приховування спадкового майна або майна, що переходить за актами дарування, з метою обходу закону про податок з нерухомості та землі, що переходять за актами дарування (ст. 63).
Примітним $є$ і те, що в ст. 60 підкреслювалося, що зазначені платежі не були сплачені, попри наявність на те можливості у платника податків. Досить обґрунтовано вживався термін «обхід закону» для опису мети в дефініції (ст. 63).

Наступною новелою стало включення до КК 1926 р. такого злочину, як виготовлення, зберігання з метою розповсюдження і поширення літературних творів, які закликають до вчинення злочинних дій, передбачених статтею 595 (ст. 597). Водночас покарання за розглянуті злочини за характером, термінами та видами залишилися колишніми.

Третім і досить значним для історії кримінального права нормативним актом став КК 1960 р. 3 урахуванням його дії аж до 2001 року він не раз піддавався змінам і доповненням, що в свою чергу позначилося і на злочинному ухиленні від сплати платежів.

Даний період характеризується жорсткою плановою економікою. Скасовувалися всі податки, збори, мита і акцизи на всій території колишнього Союзу.

У цей період податкова система в класичному іï розумінні перестала існувати [1, с. 92].

Єдиною статтею, яка передбачала відповідальність за ухилення від сплати податків в КК 1960 р., була ст. 82 «Ухилення у воєнний час від виконання повинностей або сплати податків». Зазначений склад злочину містився в розділі 2 «нші державні злочини». Водночас КК відображав тенденції лібералізації, адже за даний злочин вже не передбачалася вища міра покарання, а встановлювалося позбавлення волі до 5 років або виправні роботи.

Наступні доповнення кримінального законодавства зазначеного періоду були пов'язані з поступовим виникненням і розвитком ринкових відносин в країні. Економіка зумовила і доповнення КК 1960 р. новими складами ухилень від сплати платежів.

Так, до КК 1960 року були введені дві нові статті:

- «Приховування доходів (прибутку) чи інших об'єктів оподаткування» (ст. 1622);

- «Протидія або невиконання вимог податкової служби з метою приховування доходів (прибутку) або несплати податків» (ст. 1623).

Стаття 1622 диференціювала відповідальність залежно від розміру ухилення (подібно до чинного КК України), тобто як приховування у великих та особливо великих розмірах. Критерієм тут став мінімальний розмір оплати праці, встановлений державою.

Стаття 1623 КК криміналізувала три самостійних склади злочину: а) «Ухилення від явки до податкових органів для дачі пояснень»; б) «Відмова від дачі пояснень про прибуток»; в) «Неподання документів та іншої інформації про діяльність господарюючого суб'єкта».

Отже, знову відбулося повернення до кримінальної відповідальності за такі злочини.

Вивчення історії кримінальної відповідальності за злочинне ухилення від сплати платежів до бюджету України з моменту їі виникнення і до прийняття Кримінального кодексу України 2001 р. дозволяє зробити висновок, що найкращою конструкцією кримінальної відповідальності $\epsilon$ та, де відсутній вичерпний перелік способів ухилення (вказівка на спосіб зовсім відсутня).

Нова сторінка в історії кримінальної відповідальності за несплату податків і платежів почалася в 1996 році з прийняттям чинної Конституції України. Зокрема, 


\section{Актуальні проблеми історико-правової та міжнародно-правової науки}

одним з обов'язків, які стосуються як юридичних, так і фізичних осіб, прямо закріплених в Конституції України, $\epsilon$ обов'язок кожного платити законно встановлені податки і збори. Відповідно до ст. 67 Конституції України кожен зобов'язаний сплачувати податки і збори в порядку і розмірах, встановлених законом.

Сучасний етап розвитку кримінальної відповідальності за несплату платежів до бюджету України пов'язаний з прийняттям Кримінального кодексу України у 2001 році, а також з прийняттям Податкового кодексу України у 2010 році [3; 10].

Дані акти встановили легальні визначення податку, збору i мита, а також закріпили підстави криміналізації ухилення від їх сплати. Проте було б помилкою вважати, що розвиток законодавства, що передбачає кримінальну відповідальність за несплату податків і платежів, закінчився прийняттям цих актів, навпаки, це законодавство розвивається і нині. Коригується зміст кримінально-правових статей про злочинне ухилення від сплати платежів як шляхом внесення змін і доповнень до ст.ст. 212, 212-1 КК України, так і вдосконаленням бланкетного податкового законодавства України.

Висновки. Отже, генезис законодавства про злочинне ухилення від сплати податків та інших платежів в Україні можна з достатнім ступенем умовності розділити на такі етапи:

1) X - початок XIII ст. Даний етап характеризується оформленням фіскальних функцій давньоруської держави, а також встановленням окремих норм за ухилення від сплати податків та інших платежів. Говорити про системність відповідальності за ухилення від сплати податків і платежів в цей період не доводиться;

2) XIII-XV ст. (період монголо-татарської навали). У цей період фіскальні функції у князівств були спочатку практично повністю вилучені, потім поступово поверталися. Відповідальність за несплату платежів і податків встановлювалася окремо в кожному князівстві;

3) друга половина XV століття - перша половина XVIII століття. Етап характеризується закріпленням і оформленням системи відповідальності за несплату податків і митних платежів. В даний період з'являється такий акт, як Соборне уложення 1649 року, який формує систему відповідальності за аналізовані діяння;

4) друга половина XVIII століття - 1917 рік. Цей період характеризується кодифікаційною роботою і поступовим оформленням системи адміністративної та кримінальної відповідальності за несплату податків і платежів. Однак головною все ж таки була відповідальність адміністративна (фінансова);

5) 1917-1991 роки (радянський період). Цей період характеризується поступовим переходом від адміністративної до кримінальної відповідальності за несплату податків. Відповідальності за несплату митних платежів не було, адже держава монополізувала зовнішньоекономічну діяльність;

6) 2001 рік характеризується внесенням доповнень до кримінального законодавства, що діяло раніше, появою статей про злочинне ухилення від сплати платежів до бюджету, а також реформуванням податкового і митного законодавства;

7) сучасний період (з 2001 року і дотепер) характеризується остаточною криміналізацією діянь у формі несплати податків та інших платежів.
Отже, історичний аналіз кримінальної відповідальності за ухилення від сплати податків і платежів показує, що в усі часи в державі існували громадяни (піддані), які не бажали сплачувати податки і всіляко ухилялися від цього. Держава протягом століть намагалась зібрати максимальну кількість податків і не допустити ухилення від їх сплати.

\section{Література}

1. Артемова П.В. Уклонение от уплаты налогов: причины, сущность и исторический аспект. Вестник Саратовского государственного социально-экономического uнстumyma. 2009. № 2. С. 90-93.

2. Законодательство Петра I / В.М. Клеандрова и др. ; отв. ред. А.А. Преображенский, Т.Е. Новицкая. Москва : Юридическая литература, 1997. 879 с.

3. Кримінальний кодекс України : Закон України від 05.04.2001 р. № 5460-VI (5460-17). URL: http: //zakon1.rada.gov.ua.

4. Лаврентьевская летопись : Полное собрание русских летописей / под ред. Е.Ф. Карского. Т. 1. Вып. 1-3. 4 изд. Москва : Наука, 2007. 496 с.

5. Митний кодекс України : Закон України від 13.03.2012 p. № 4495-VI. URL: http: //zakon1.rada.gov.ua.

6. Новое уголовное уложение, Высочайше утвержденное 22 марта 1903 года. Санкт-Петербург : Изд. В.П. Анисимова, 1903. 250 с.

7. Российское законодательство X-XX веков : Законодательство периода становления абсолютизма. В 9-ти томах. Т. 4 ... 1667 г., апреля 22. Новоторговый устав. Введение. О.И. Чистякова; отв. ред. тома А.Г. Маньков. Москва : Юрид. лит., 1986. 512 с.

8. Памятники русского права. Москва : Госюриздат, 1955. Вып. 3. 527 с.

9. Петров Ю.И. Фискальные органы в истории налогообложения в России: IX-XIX века. Москва, 2016. 240 с.

10. Податковий кодекс України : Закон України від 02.12.2010 p. № 2755-VI. URL: http://zakon1.rada.gov.ua.

11. Чистяков О.И. Российское законодательство X-XX веков в 9 т. Том 3. Москва : Юридическая литература, 1985. $512 \mathrm{C}$

12. Соборное уложение 1649 года / ред. коллегия: В.И. Буганов, М.П.Ирошников, А.Г. Маньков (рук. авт. колл.), В.М. Панеях. Ленинград: Наука, Ленингр. отд-ние, 1987. 448 с.

13. Статистический ежегодникъ Новгородскаго Губернского Земства за 1912 годъ : Новгород : Типография Л.С. Селивановой, 1914, за 1914 год : т. 2. 1912. Вып. 10 : Кирилловский уезд. 146 с.

14. Таможенный Устав 1819 года : Полное Собрание Законов Российской Империи : Собрание первое : С 1649 по 12 декабря 1825 года. Санкт-Петербург : Тип. ІІ Отд-ния собств. Е.И.В. канцелярии, 1830. 740 с.

15. Хозяйственные преступления. Текст и комментарий к ст. ст. 126-141 Уголовного кодекса. Трайнин А.Н. 3-е изд. Москва : Право и Жизнь, 1925. 107 с.

16. Уложение о наказаниях уголовных и исправительных 1845 г. (утратило силу). Санкт-Петербург, 1845. 920 с.

17. Устав благочиния или полицейский. Российское законодательство X-XX вв. В 9 т. Т. 4. Законодательство периода становления абсолютизма / отв. ред. А.Г. Маньков. Москва : Юридическая литература, 1986. 512 с.

Гритенко О. А., кандидат юридичних наук, доцент, завідувач кафедри кримінального права та кримінології одеського державного університету внутрішніх справ

Старинець $\epsilon$. A., аспірант кафедри кримінального права та кримінології Одеського державного університету внутрішніх справ 